\title{
Physicochemical and Microbiological Examination of Hand-dug wells, Boreholes and Public Water Sources in selected areas of Ibadan, Nigeria
}

\section{*11ADEDEJI, OLUDARE H; OLAYINKA, OLUFUNMILAYO O; OLADIMEJI, OLANIYI}

\author{
Department of Environmental Management and Toxicology, \\ Federal University of Agriculture, PMB 2240, Abeokuta, Nigeria \\ Corresponding author's Email: adedejioh@funaab.edu.ng Phone: +2348055414347
}

\begin{abstract}
This study examined some physicochemical and microbiological characteristics of some water sources and evaluates their health implications in selected areas of Ibadan, Nigeria. Forty (40) water samples were collected into 1-litre plastic kegs from hand-dug wells, boreholes and public water points between June 12 and July 11, 2014. Samples were analysed for physical, chemical and microbial parameters using standard procedures. Well-structured questionnaires were used to elicit information on sanitation conditions in the areas. Electrical conductivity in many of the sampled water were higher than the recommended limit, while TDS were within the desirable limit of $200 \mathrm{mg} / \mathrm{l}$ except for the borehole at Ita-Baale Borehole (IB) and hand dug well at Oke-Aare $(\mathrm{OAH})$. Microbial assessment of water samples in most areas confirmed the presence of vibrio species due to faecal pollution. Bacterial isolates identified in some of the water samples were Enterobacter cloaca, Escherichia coli, Klebsiella oxytoca, Pseudomaonas fluorescens and Salmonella spp. The study revealed that sanitary facilities including toilets and improved latrines are lacking in many areas. Hand dug wells had the highest frequency of occurrence pollutants and bacteria due to their close proximity to pit latrines. The study concluded that residents in the study area are exposed to polluted water sources, which pose serious threat their health. This study added to the existing data on the inadequacy of sanitation in urban centres in the country hence the need for increased effort in the provision of more cleaner and well protected water sources such boreholes and piped-borne water. @JASEM
\end{abstract}

\section{https://dx.doi.org/10.4314/jasem.v21i3.19}

Keywords: Hygiene, microbial contamination, sanitation, urban slums, water quality, health

Worldwide, about 1.1 billion of the population lacked safe water and 2.4 billion lacked adequate sanitation (WHO, 2012) resulting in widespread of water- and sanitation-related diseases. Sanitation generally refers to the provision of improved facilities and services for the safe collection, storage, and appropriate disposal of wastes ranging from domestic, industrial, commercial, medical, and hazardous wastes. (Oke et al., 2013). An improved sanitation facility is one that hygienically separates human excreta from human contact and it generally involves physically closer facilities, less waiting time, and safer disposal of excreta (Hutton and Haller, 2004). Nearly 250 million cases of water- and sanitation-related diseases are reported every year, with more than 3 million deaths annually-about 10,000 a day (WHO/UNICEF, 2012). The report by the Joint Monitoring Programme further revealed that as at 2011 in Nigeria, only $31 \%$ of the population has access to improved sanitation facilities such as flush toilets, $24 \%$ uses shared facilities while $22 \%$ uses unimproved facilities and $23 \%$ defecate in the open (WHO/UNICEF, 2012). This problem is exacerbated by high population density, which results in overcrowding, inadequate planning and poor urban governance.

Although lack of good sanitation varies from place to place, it is more pronounced in the urban centres, especially in developing and under-developed countries. In major cities in sub-Saharan Africa, most people do not have access to a hygienic toilet and large amounts of faecal waste are discharged to the environment without adequate treatment. This is likely to have major impacts on infectious disease burden and quality of life (Hutton et al., 2007). Ayeni (2014) reported that increasing population of urban centres has been a major contributor to unsanitary environment, continuous use of unimproved sources of water increased the risk of environmental health problems such as cholera incidence. Inadequate access to safe water and 
sanitation services, coupled with poor hygiene practices, kills and sickens thousands of children every day, and leads to impoverishment and diminished opportunities for thousands more (Allen et al., 2006; WHO, 2009). In view of the importance of water in our daily life and state of sanitation of the sources of water supply, it is imperative to conduct thorough microbiological and physico-chemical examinations especially in low-income urban settlements. The aim of the study is to examine some physicochemical and microbiological characteristics of some water sources and evaluate their health implications in selected areas of Ibadan, Nigeria.

\section{MATERIALS AND METHODS}

Description of the Study Area: Ibadan, the capital of Oyo state, is Nigeria's second largest urban agglomeration, with a population of 3.3 million people (Brinkhoff, 2010). Ibadan is located on longitude $7^{\circ} 2^{\prime}$ to $7^{\circ} 40^{\prime} \mathrm{E}$ and latitude $3^{\circ} 35^{\prime}$ to $4^{\circ} 10^{\prime} \mathrm{N}$ (Figure 1).

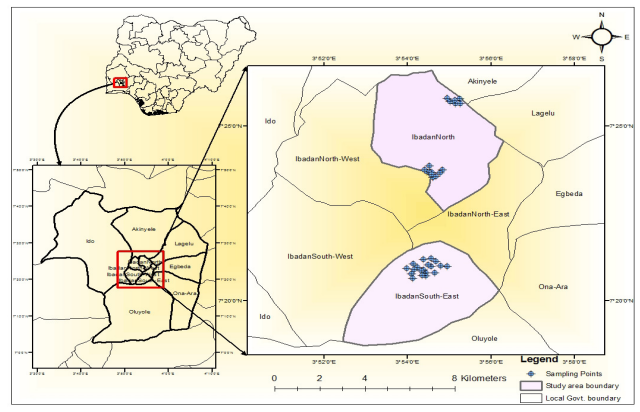

Fig 1: Ibadan North and Ibadan Southeast Local Governments Areas showing Sampling points

Ibadan North and Ibadan Southeast chosen as study area contain the largest slum areas in the city and the characteristics of these two LGAs, which fit the criteria for slums, include high density of population, poor sanitation, inadequate health, education and social facilities, inaccessible road network, lack of potable water, and erratic electricity supply (Olusola et al., 2012). The areas selected for the purpose of this study (Table 1) were carefully selected based on the varying sanitary conditions. The present features of sanitation practices in most parts of the study area are poorly managed solid-waste and drainage, poor transportation facilities, inadequate public utilities and social infrastructure, poor housing conditions as well as foul odour

Table 1: Selected locations within the two local governments

\begin{tabular}{ll}
\hline Local Government & Selected Areas \\
\hline Ibadan North & Beere, Bodija, Oke-Are, Kara, Ashi \\
Ibadan South East & Kobomoje, Oja-Oba, Eleta, Olubi, Elekuro, Agbongbon, Ita-Baale \\
\hline
\end{tabular}

Water Sampling: Specific areas were selected from the two local governments based on their rather bad sanitary conditions. The areas also represent the core of ancient Ibadan metropolis. Forty (40) water samples were collected into 1-litre plastic kegs from hand-dug wells, boreholes and public water points between June 12 and July 11, 2014 in the selected areas. The water was left to run from the source for about 4 min to equate the minimum number of well volume and to stabilize the electrical conductivity (Mor et al., 2006). Samples for microbiological analysis were aseptically taken in $50 \mathrm{ml}$ sterile universal containers. All samples were transported to the laboratory on ice to stop reproduction and bias that may occur at ambient temperature. A handheld GPS devise was used in determining the coordinates of the sampling points for this study.
Chemical analysis: Three water samples each were taken from the boreholes, hand-dug wells and stream used by the people were analysed for physical and chemical properties. Water samples were stored at $4^{\circ} \mathrm{C}$ in the fridge prior to analysis. Temperature, $\mathrm{pH}$, and electrical conductivity (EC) were measured in situ using Hanna combo portable meter (APHA, 2005). It was rinse with distilled $\mathrm{H}_{2} \mathrm{O}$, inserted into the sample, and allowed several minutes to stabilize before record reading. DO was determined by Winkler Azide Modification Titrimetric, while the DO method was used after five days for BOD. Chemical oxygen demand (COD) was determined using a strong oxidizing agent (potassium dichromate) $\mathrm{K}_{2} \mathrm{Cr}_{2} \mathrm{O}_{7}$ and sulphuric acid at $148^{\circ} \mathrm{C}$ with back titration (APHA, 2005). Ammonia was determined following the procedure used by Hendriksen et al. (2012) while nitrate was 
determined using the Ion Chromatography Method (APHA 4110B).Total Dissolved Solids (TDS) was determined gravimetrically (APHA, 2005) and chloride by Argentometric Titration (Mohr's method).

Microbial properties: Microbial properties of water samples including thiosulphate Citrate Bile Salt (TCBS), total bacteria count (TBC), and Escherichia coli $(E$. coli) were recovered and enumerated via culture-based most probable number (MPN) techniques in compliance with EPA guidelines (EPA, 2009). Salmonella concentrations for well water samples were determined by the method described by Krometis et al. (2010). The media were boiled using Electro thermal bath. Plate count analysis was conducted using McConkey agar and the plates were incubated at $37^{\circ} \mathrm{C}$ for $24 \mathrm{~h}$ to detect red colonies on the incubated Petri dishes. The plate were examined, then left for another $24 \mathrm{~h}$ at room temperature and reexamined. all analyses were performed by the membrane filtration technique with Millipore filters and equipment (Millipore Corp., Bedford, Mass.). All samples were transported to the laboratory on ice to stop reproduction and bias that may occur at ambient temperature.

Identification of isolates: The bacteria isolates were identified by cultural features (i.e. colour, shape, edge, etc.), morphological characteristics (motility, Gram-reaction, cell arrangement and shape) and biochemical features (indole, lactase oxidase, coagulase, catalase, sucrose, citrate etc.).

Statistical analysis: Descriptive statistics (mean and standard deviations) were analyzed using Statistical Package for Social Sciences (SPSS 17.0) while other results were presented using graphs prepared using Microsoft Excel.

\section{RESULTS AND DISCUSSION}

Physical and chemical properties of water samples: Physical and chemical properties of water samples collected from boreholes, hand dug wells and stream in the study area with their standard values as prescribed by WHO are presented in Table 2 . The $\mathrm{pH}$ ranges between 8.06 in water from a hand dug well at Kobomoje to 9.03 in water from a borehole in Agbongbon. Water $\mathrm{pH}$ recorded for the borehole in Agbongbon was slightly higher than the range of 6.0-9.0 standard limit of World Health Organization (WHO, 2011a). Temperature varies from 27.09 to $29.01^{\circ} \mathrm{C}$. Electrical conductivity (EC) ranged from mean $\pm \mathrm{SD}$ of $255.32 \pm 45.04 \mu \mathrm{Scm}^{-1}$ at Elekuro Borehole in Ibadan South East LGA to $657.06 \pm 32.74 \mu \mathrm{Scm}^{-}$at the Ita-Baale Borehole also in Ibadan South East LGA (Table 2). EC in many of the sampled water from different parts of the study areas were higher than the recommended limit of 500 $\mathrm{mg} / \mathrm{l}$ (WHO, 2011). Electrical conductivity indicates that the content of soluble and high conducting salts present in the water samples. Total dissolved solid (TDS) varies proportionately as the EC. Highest TDS of $132.1 \pm 0.55 \mathrm{mg} / \mathrm{l}$ was recorded at Ita-Baale Borehole, which incidentally had the highest EC. Studies have shown that some TDS act as conductors and thus contribute to conductance (Harilal et al., 2004). All samples contains TDS within the desirable limit of $200 \mathrm{mg} / \mathrm{l}$ except for the borehole at Ita-Baale Borehole (IB) and hand dug well at OkeAare $(\mathrm{OAH})$, which were $227.1 \mathrm{mg} / \mathrm{l}$ and $217.0 \mathrm{mg} / \mathrm{l}$ respectively. High TDS makes water make it unpalatable and potentially unhealthy (Barnes et al., 1998). Nitrate concentration in the water samples varied from 23.03 in borehole at Elekuro to $60.01 \mathrm{mg} / \mathrm{l}$ in Kobomoje Hand dug well. The $60.01 \mathrm{mg} / \mathrm{l}$ recorded in Kobomoje exceeded the 50 $\mathrm{mg} / \mathrm{l}$ stipulated for nitrate in drinking water (WHO, 2011). Oxidation of vegetable and animal debris and animal excrement mainly from agricultural, domestic and industrial discharges and improperly managed municipal wastewaters and septic tanks were reported as the main sources of nitrate and nitrite into drinking water (Fewtrell, 2004; WHO, 2011b). Although the occurrence of infantile methaemoglobinaemia to nitrate in drinking water (Dzwairo et al., 2006), recent evidence from research suggests that diarrhoea and/or gastrointestinal infection, not ingested nitrate, are the principle causative factors in infantile methaemoglobinaemia or the blue-baby syndrome (Avery, 1999; Addison and Benjamin; 2004; WHO, 2011a; Abou El-Gheit et al. (2012).). According to IARC (2005), ingested nitrate or nitrite under conditions that result in endogenous nitrosation is probably carcinogenic to humans. A minimal risk level (MRL) of $4 \mathrm{mg} / \mathrm{kg} / \mathrm{d}$ was quoted for acuteduration oral exposure (1 to 14 days), intermediateduration oral exposure (15 - 364 days) and chronicduration oral exposure ( $>364$ days) for nitrate (ATSDR, 2015). Ammonia concentrations in the water samples were all within the limit of $1.5 \mathrm{mg} / \mathrm{l}$ according to WHO (WHO, 2011b). 
Table 2: Physical and chemical properties of Borehole and hand dug well water from selected areas

\begin{tabular}{|c|c|c|c|c|c|c|c|}
\hline Location & $\mathrm{pH}$ & Temp $\left({ }^{\circ} \mathrm{C}\right)$ & $\mathrm{EC}\left(\mu \mathrm{Scm}^{-1}\right)$ & TDS (ppm) & $\begin{array}{l}\text { Nitrate } \\
(\mathrm{mg} / \mathrm{L}\end{array}$ & $\begin{array}{l}\begin{array}{l}\text { Chloride } \\
(\mathrm{mg} / \mathrm{L})\end{array} \\
\end{array}$ & Ammonia \\
\hline \multicolumn{8}{|l|}{ Ibadan South East } \\
\hline EH & $8.75 \pm 0.19$ & $28.47 \pm 1.36$ & $479.00 \pm 15.19$ & $89.6 \pm 8.13$ & 36.12 & 42.05 & 0.33 \\
\hline $\mathrm{AH}$ & $8.89 \pm 0.23$ & $28.03 \pm 0.45$ & $619.67 \pm 72.86$ & $123.7 \pm 14.7$ & 40.05 & 46.24 & 0.67 \\
\hline $\mathrm{OH}$ & $8.26 \pm 1.17$ & $27.8 \pm 0.36$ & $492.33 \pm 92.09$ & $99.3 \pm 4.05$ & 32.45 & 36.03 & 0.56 \\
\hline EB & $8.56 \pm 0.57$ & $28.30 \pm 0.88$ & $255.32 \pm 45.04$ & $48.3 \pm 0.72$ & 23.03 & 45.09 & 0.23 \\
\hline $\mathrm{KbH}$ & $8.06 \pm 0.70$ & $28.10 \pm 1.22$ & $607.00 \pm 27.08$ & $120.9 \pm 3.02$ & 60.01 & 46.24 & 1.25 \\
\hline IB & $8.19 \pm 0.36$ & $29.00 \pm 0.08$ & $657.06 \pm 32.74$ & $227.1 \pm 0.55$ & 52.07 & 50.05 & 1.45 \\
\hline $\mathrm{OOB}$ & $8.45 \pm 0.24$ & $29.20 \pm 0.04$ & $559.03 \pm 26.03$ & $334.1 \pm 0.31$ & 48.04 & 47.03 & 1.21 \\
\hline $\mathrm{OOH}$ & $8.23 \pm 0.16$ & $28.23 \pm 0.05$ & $537.02 \pm 22.54$ & $327.3 \pm 0.48$ & 50.03 & 43.07 & 0.65 \\
\hline $\mathrm{IH}$ & $8.06 \pm 0.21$ & $28.62 \pm 0.17$ & $608.02 \pm 12.63$ & $231.1 \pm 0.48$ & 47.05 & 47.03 & 0.67 \\
\hline $\mathrm{AB}$ & $9.03 \pm 0.07$ & $28.40 \pm 0.73$ & $523.18 \pm 20.13$ & $104.6 \pm 5.06$ & 48.04 & 56.03 & 0.82 \\
\hline \multicolumn{8}{|l|}{ Ibadan North } \\
\hline $\mathrm{BdH}$ & $8.65 \pm 0.23$ & $27.09 \pm 1.22$ & $388.32 \pm 23.76$ & $72.9 \pm 1.04$ & 33.02 & 28.05 & 0.12 \\
\hline $\mathrm{BdB}$ & $8.48 \pm 0.54$ & $28.32 \pm 1.03$ & $456.02 \pm 45.21$ & $102.1 \pm 0.52$ & 43.06 & 47.05 & 0.20 \\
\hline $\mathrm{BH}$ & $8.59 \pm 0.22$ & $28.33 \pm 0.88$ & $502.56 \pm 82.11$ & $124.6 \pm 1.21$ & 53.27 & 50.04 & 0.25 \\
\hline BS & $8.31 \pm 1.02$ & $29.01 \pm 0.45$ & $556.21 \pm 13.04$ & $115.6 \pm 0.61$ & 56.05 & 47.01 & 0.45 \\
\hline $\mathrm{OAH}$ & $8.62 \pm 0.35$ & $27.98 \pm 1.02$ & $625.02 \pm 32.03$ & $217.0 \pm 1.04$ & 53.08 & 53.47 & 1.06 \\
\hline $\mathrm{OAB}$ & $8.71 \pm 0.62$ & $28.35 \pm 0.66$ & $445.63 \pm 35.26$ & $100.1 \pm 0.65$ & 34.8 & 28.02 & 0.27 \\
\hline $\mathrm{KH}$ & $8.29 \pm 0.29$ & $28.22 \pm 1.36$ & $574.04 \pm 32.06$ & $104.1 \pm 0.38$ & 37.07 & 28.23 & 0.96 \\
\hline $\mathrm{KB}$ & $8.43 \pm 0.17$ & $28.47 \pm 0.53$ & $495.12 \pm 18.48$ & $98.4 \pm 1.02$ & 29.05 & 27.04 & 0.15 \\
\hline AsB & $8.64 \pm 0.34$ & $28.30 \pm 0.43$ & $373.04 \pm 24.67$ & $78.3 \pm 0.58$ & 26.05 & 28.03 & 0.34 \\
\hline $\mathrm{AsH}$ & $8.42 \pm 0.51$ & $29.03 \pm 0.48$ & $346.06 \pm 25.53$ & $84.3 \pm 0.54$ & 34.03 & 37.04 & 0.56 \\
\hline WHO Standards* & $6.0-9.0$ & Ambient & 500 & 200 & 50 & 250 & 1.50 \\
\hline
\end{tabular}

*WHO (2011a)

Note: $\mathrm{AB}=$ Agbongbon Borehole; $\mathrm{AH}=$ Agbongbon Hand dug well; AsB=Ashi Borehole; BdH=Bodija Hand dug well, $\mathrm{BdB}=$ Bodija Borehole; $\mathrm{BH}=$ Beere Hand dug well, BS=Beere Stream; EH=Eleta Hand dug well; EB= Elekuro Borehole; $\mathrm{IB}=$ Ita-Baale Borehole; $\mathrm{IH}=$ Ita-Baale Hand dug well; $\mathrm{KB}=\mathrm{Kara}$ Borehole; $\mathrm{KH}=\mathrm{Kara}$ Hand dug well; $\mathrm{KbH}=\mathrm{Kobomoje} \mathrm{Hand}$ dug well; $\mathrm{OAB}=\mathrm{Oke}$ Aare Borehole; $\mathrm{OAH}=\mathrm{Oke}$ Aare Hand dug well; $\mathrm{OH}=\mathrm{Olubi}$ Hand dug well; $\mathrm{OOB}=\mathrm{Oja} \mathrm{Oba} \mathrm{Borehole}$, $\mathrm{OOH}=\mathrm{Oja}$ Oba Hand dug well

Highest con concentration of ammonia was $1.45 \mathrm{mg} / \mathrm{l}$ found in water sample from Ita-Baale while the lowest of $0.12 \mathrm{mg} / \mathrm{l}$ was found in Bodija Hand dug well. Ammonia can enter the well or borehole directly from nearby latrine waste or following denitrification of nitrate released from latrines (Ahmed et al. 2002; Dzwairo et al. 2006). Concentration of chloride in the water samples in this study varied between $27.04 \mathrm{mg} / \mathrm{l}$ in Kara Borehole in Ibadan North LGA and 56.03 in Agbongbon Borehole in Ibadan South East LGA. The values obtained for chloride in this study were all within the standard limit set by the World Health Organization (WHO, 2011b). High concentrations of chloride are common in soils closest to latrines, from where it can be transported with minimal retention during groundwater flow (Banks et al., 2002).

Microbial Characteristics: The result of the microbial analysis of water samples taken from the selected points is presented in Table 3. Thiosulphate
Citrate Bile Salt (TCBS) is positive in the water samples taken from bore holes in Agbongbon (AB), Elekuro (EB), Elekuro Hand dug well (EH), and Oja Oba Hand dug well $(\mathrm{OOH})$ in Ibadan South East LGA. TCBS was also positive in Bodija Hand dug well $(\mathrm{BdH})$, Bodija Borehole $(\mathrm{BdB})$, Oke Aare Borehole $(\mathrm{OAB})$ and Ashi Hand dug well (AsH) in Ibadan North LGA. The positive value confirms the presence of vibrio species in the water samples. Total bacteria count (TBC) ranges from $1.85 \times 10^{1}$ in water sample from Oja-Oba Borehole (OOB) and $3.82 \mathrm{x}$ $10^{4}$ in Beere stream (BS) which is surface water exposed to direct dumping of domestic waste and faecal matter. Generally, the hand-dug wells showed greater contamination levels. Escherichia coli $(E$. coli) count ranges from zero to $6.93 \times 10^{2}$, while the total salmonella count ranges from zero to $9.11 \times 10^{2}$. E. coli belongs to the faecal coliform group and is specific to the intestinal tract of warm-blooded animals (Washington State Department of Health, 2012). 
Table 3: Microbial properties of water samples

\begin{tabular}{lllll}
\hline Location & TCBS & $\begin{array}{c}\text { TBC } \\
(\mathrm{CFU} / \mathrm{ml})\end{array}$ & E. coli CFU/ml) & $\begin{array}{l}\text { Salmonella } \\
(\mathrm{CFU} / \mathrm{ml})\end{array}$ \\
\hline Ibadan South East & + & $7.25 \times 10^{2}$ & $6.93 \times 10^{2}$ & 0 \\
EH & - & $8.55 \times 10^{2}$ & 0 & 0 \\
$\mathrm{AH}$ & - & $6.20 \times 10^{3}$ & $1.00 \times 10^{1}$ & $1.13 \times 10^{1}$ \\
OH & + & $2.00 \times 10^{2}$ & 0 & 0 \\
$\mathrm{~EB}$ & - & $1.78 \times 10^{3}$ & $3.25 \times 10^{2}$ & $2.26 \times 10^{1}$ \\
$\mathrm{KbH}$ & - & $6.30 \times 10^{1}$ & $2.50 \times 10^{2}$ & 0 \\
$\mathrm{IB}$ & & $3.05 \times 10^{2}$ & $1.50 \times 10^{2}$ & 0 \\
$\mathrm{IH}$ & + & $2.75 \times 10^{2}$ & $2.50 \times 10^{2}$ & 0 \\
$\mathrm{AB}$ & - & $1.85 \times 10^{1}$ & 0 & 0 \\
OOB & + & $3.16 \times 10^{6}$ & $9.40 \times 10^{1}$ & $6.67 \times 10$ \\
OOH & & & & \\
Ibadan North & + & $1.02 \times 10^{4}$ & $1.63 \times 10^{2}$ & $6.67 \times 10$ \\
BdH & + & $4.97 \times 10^{3}$ & $6.85 \times 10^{2}$ & $3.72 \times 10^{2}$ \\
BdB & - & $3.29 \times 10^{3}$ & $6.33 \times 10^{1}$ & $7.00 \times 10^{1}$ \\
BH & - & $3.82 \times 10^{4}$ & $6.13 \times 10^{2}$ & $4.42 \times 10^{1}$ \\
BS & - & $3.30 \times 10^{4}$ & $4.89 \times 10^{2}$ & $3.48 \times 10^{1}$ \\
OAH & + & $2.95 \times 10^{3}$ & $2.33 \times 10^{2}$ & $1.67 \times 10^{2}$ \\
OAB & - & $1.16 \times 10^{4}$ & $1.55 \times 10^{2}$ & $1.06 \times 10^{2}$ \\
KH & - & $2.34 \times 10^{4}$ & $9.83 \times 10^{1}$ & $9.11 \times 10^{2}$ \\
KB & - & $9.18 \times 10^{3}$ & $3.04 \times 10^{1}$ & $4.44 \times 10^{2}$ \\
AsB & + & $3.23 \times 10^{3}$ & $6.02 \times 10^{2}$ & $3.65 \times 10^{1}$ \\
AsH & - & $1.00 \times 10^{2}$ & $0 / 100 \mathrm{CFUml}$ & $0 / 100 \mathrm{CFUml}{ }^{-1}$ \\
WHO Standards* & & & &
\end{tabular}

*WHO (2011a)

Note: $\mathrm{AB}=$ Agbongbon Borehole; $\mathrm{AH}=\mathrm{Agbongbon}$ Hand dug well; $\mathrm{AsB}=\mathrm{Ashi}$ Borehole; $\mathrm{AsH}=\mathrm{Ashi}$ Hand dug well, $\mathrm{BdH}=$ Bodija Hand dug well, $\mathrm{BdB}=$ Bodija Borehole; $\mathrm{BH}=\mathrm{Beere}$ Hand dug well, BS=Beere Stream; $\mathrm{EH}=$ Eleta Hand dug well; $\mathrm{EB}=$ Elekuro Borehole; $\mathrm{IB}=\mathrm{Ita}-\mathrm{Baale}$ Borehole; $\mathrm{IH}=\mathrm{Ita}-\mathrm{Baale}$ Hand dug well; $\mathrm{KB}=$ Kara Borehole

Epidemiological evidences have shown that total coliforms and Escherichia coli are good indicators of water quality (Wade et al. 2003; Verhille, 2013). In majority of the cases in this study, TBC and Escherichia coli were in concentrations far higher than the recommended limits due to possible leaching of excreta from the many not well-constructed pit latrines into groundwater sources. The use of unprotected pit latrines may cause severe human and ecological health impacts including diseases associated with microbiological and chemical contamination of shallow groundwater sources (Blackburn et al., 2004; Caincross, 2004; Pedley et al. 2006) as well as inadequate personal hygiene (Olowe et al., 2005). Bacterial isolates identified in some of the water samples were Enterobacter cloaca, Escherichia coli, Klebsiella oxytoca, Pseudomaonas fluorescens and Salmonella spp (Table 4). 
Table 4: Bacteria Isolates in water samples

\begin{tabular}{|c|c|c|c|c|c|c|c|c|c|c|c|c|c|c|c|c|c|}
\hline 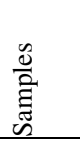 & 节 & 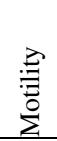 & 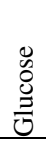 & 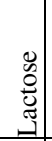 & $\begin{array}{l}\bar{P} \\
\text { 总 } \\
\text { 耍 }\end{array}$ & $\begin{array}{l}0 \\
\stackrel{0}{0} \\
\stackrel{3}{\pi} \\
\Sigma\end{array}$ & $\frac{0}{0}$ & 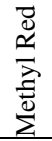 & 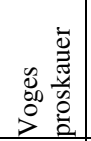 & 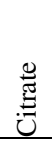 & $\begin{array}{l}2 \\
I\end{array}$ & 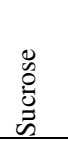 & Jँّ & 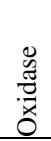 & $\begin{array}{l}0 \\
\tilde{\Xi} \\
\tilde{\Xi} \\
\tilde{0} \\
0 \\
0\end{array}$ & 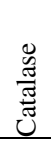 & $\begin{array}{l}\frac{0}{5} \\
0 \\
0 \\
0\end{array}$ \\
\hline $\mathrm{AH}$ & GNB & - & + & - & - & - & - & - & - & + & - & + & - & - & - & + & Klebsiella oxytoca \\
\hline $\mathrm{KbH}$ & GNB & + & + & + & - & - & - & + & + & + & + & + & + & - & NA & + & $\begin{array}{l}\text { Pseudomaonas } \\
\text { fluorescens }\end{array}$ \\
\hline $\mathrm{KH}$ & GNB & + & + & + & + & + & - & - & - & + & - & + & - & - & - & + & Enterobacter cloaca \\
\hline $\mathrm{OH}$ & GNB & + & + & + & + & + & + & + & - & - & - & NA & - & - & NA & + & Escherichia coli \\
\hline $\mathrm{OOB}$ & GNB & + & + & - & - & - & - & + & - & + & + & + & - & - & NA & + & Salmonella spp \\
\hline $\mathrm{OOH}$ & GNB & + & + & - & - & - & - & + & - & + & + & + & - & - & NA & + & Salmonella spp \\
\hline $\mathrm{IH}$ & GNB & + & + & + & + & + & + & + & - & - & - & NA & - & - & NA & + & Escherichia coli \\
\hline BS & GNB & + & + & + & - & + & - & + & + & + & + & + & + & + & NA & + & $\begin{array}{l}\text { Pseudomaonas } \\
\text { fluorescens }\end{array}$ \\
\hline
\end{tabular}

Note $+=$ Positive, $-=$ Negative, GNB= Gram Negative Bacilli, NA= Not Applicable AH=Agbongbon Hand dug well; $\mathrm{BS}=$ Beere Stream; $\mathrm{IH}=$ Ita-Baale Hand dug well; $\mathrm{KH}=\mathrm{Kara}$ Hand dug well; $\mathrm{KbH}=\mathrm{Kobomoje}$ Hand dug well; $\mathrm{OH}=\mathrm{Olubi}$ Hand dug well $\mathrm{OOB}=\mathrm{Oja}$ Oba Borehole, $\mathrm{OOH}=$ Oja Oba Hand dug well

The isolates were characterized based on their cultural, morphological as well as biochemical features. Bacterial isolates were mostly positive based on morphological feature (motility) and biochemical features (glucose and catalase), while oxidase is mostly negative. These organisms are largely responsible for some of the sanitation-related diseases highlighted in Table 3. Coliform group density is a criterion of the degree of pollution and sanitary quality (Benjamen and James, 2014). The presence of $E$. coli is an indicator of faecal contamination which could increase the susceptibility of the residents to several infections e.g. meningitis, acute renal failure and diarrhoea which is one of the leading cause of morbidity and mortality among young children (NIS, 2007). Faecal coliforms are a smaller group in the total coliform family that inhibit the intestines of mammals and have a relatively short lifespan.

Sanitary Conditions: Many households in the study areas cannot afford to build improved latrine as corroborated by other similar studies (Songsore and McGranahan, 1998; Osumanu, 2007) that revealed that poor households are often unable to afford a toilet facility at home. In some parts such as Beere, Eleta, Kara and Kobomoje some people defecate in open areas in areas without latrines and faeces could be seen dotting some spots in the neighbourhood. There is hardly any public toilet and where the public toilets area available, such facilities area in various state of disuse. In some instances, people avoid public toilets for fear of contacting diseases and therefore defecate in the open. Osumanu et al. (2013) stressed that public toilet is an unavoidable option for sanitation in many low-income towns and cities of developing countries because in the absence of public toilet facilities people may be forced to defecate in the open (Ayee and Crook, 2003; MLGRD, 2010). Although $25 \%$ of the households surveyed had access to public piped water source of drinking water, they resort to other sources when the pubic tap water is not available. Public piped water service is erratic in majority of the areas. Investigation in the study area also indicated that household also depends on water purchased from water vendors whose source and quality of water sold cannot be guaranteed. Many existing water sources were not functioning thus increasing poor hygiene conditions in the area. The quality and quantity of water available for drinking and other domestic uses are grossly inadequate within the areas; thus leading the residents to adopt unimproved sources of water which pose serious danger to their health. In Olubi area, it was discovered that a former soak away pit is now being used as a well. Unsanitary condition of the environment also lead to breeding sites for vectors of diseases like mosquito which transmit malaria, with open refuse dumps serving as hiding and breeding sites for rats which transmits various kinds of infections. Although $38 \%$ of the households surveyed indicated that they dispose wastes using government approved agencies while about $28 \%$ of the households dispose wastes on undeveloped/abandon plots nearby (Figure 2). 


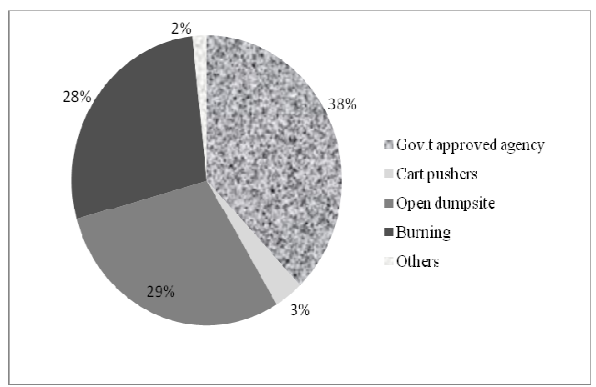

Fig 2: Means of waste disposal

Medical Records: Although available medical records between 2009 and 2012 a steady reduction in the number of reported cases of sanitation related diseases (Table 5) properly due to the adoption of improved sanitation methods and water supply. Incidences of typhoid and diarrhoea were very high in 2009, 2011 and 2012 although no mortality was reported.

Table 5: Epidemiological Records of Oyo state

\begin{tabular}{lllllll}
\hline Year & Cholera & & Typhoid & \multicolumn{3}{c}{ Diarrhoea } \\
\cline { 2 - 7 } & Cases & Mortality & Cases & Mortality & Cases & Mortality \\
2009 & 1025 & 1 & 19,961 & 74 & NA & NA \\
2010 & NA & NA & NA & NA & NA & NA \\
2011 & 978 & 3 & 7546 & 89 & 22,129 & NA \\
2012 & 433 & 1 & NA & NA & 16,942 & NA \\
\hline
\end{tabular}

Source: Oyo State Ministry of Health, Statistics Division)

There is paucity of epidemiological data on sanitation related diseases as shown in Table 5 as no data was available for 2010 and the data gathered was for the entire state, hence not location specific. In many instances, such cases are not reported because people seek alternative medical care, which are not recorded in the government hospitals.

Conclusion: Groundwater sources in the study area are mostly unprotected and close to the pit latrines thus increasing susceptibility to contamination. Water quality parameter such as electrical conductivity in many areas were higher than the recommended limit while microbial assessments of the water used in some of the areas were positive confirming the presence of vibrio species due to faecal pollution. There is a need for to prioritizing sanitation and hygiene by the provision of cleaner and wellprotected water sources, and adequate waste disposal to reduce associated health implications.

\section{REFERENCES}

Abou El-Gheit, EN; Abdo, MH; Mahmoud, SA (2012). Impacts of Blooming Phenomenon on Water Quality and Fishes in Qarun Lake, Egypt. International Journal of Environmental Science and Engineering, 3, 11- 24

Addison, TM; Benjamin, N (2004). Nitrate and human health. Soil Use and Management, 20: 98-104.
Ahmed, KM; Khandkar, ZZ; Lawrence, AR; Macdonald, DMJ; Islam, MS (2002). Appendix A: an investigation of the impact of on-site sanitation on the quality of groundwater supplies in two peri-urban areas of Dhaka, Bangladesh. In: Assessing Risk to Groundwater from On-site Sanitation: Scientific Review and Case Studies. Keyworth, UK: British Geological Survey, 37-67. Available at: http://r4d.dfid.gov.uk/pdf/outputs/r68692.pdf [Accessed 12 June 2015].

Allen, A; Dávila, J; Hofmann, P (2006). Governance of water and sanitation services for the Periurban poor: A framework for understanding and action in Metropolitan Regions. London, England: The Development Planning Unit University College London.

APHA (2005). Standard Methods for the Examination of Water and Wastewater (21st Edition).Washington: American Public Health Association, American Water Works Association, Water Environment Federation. ATSDR (2015).

(http://www.atsdr.cdc.gov/mrls/pdfs/atsdr_mrls.p df)

Avery, AA (1999). Infantile methaemoglobinaemia: re-examining the role of drinking water nitrates. 
Environ Health Perspect. 107 (7): 583-586. Available at:

http://www.ncbi.nlm.nih.gov/pmc/articles/PMC1 566680/ [Accessed 12 June 2015].

Ayee, J; Crook, R (2003). Toilet wars": urban sanitation services and the politics of publicprivate partnerships in Ghana. IDS Working Paper 213. Institute of Development Studies, Brighton, Sussex BN1 9RE England

Ayeni, AO (2014). Domestic Water Source, Sanitation and High Risk of Bacteriological Diseases in the Urban Slum: Case of Cholera in Makoko, Lagos, Nigeria. Journal of Environment Pollution and Human Health. 2(1): 12-15.

Banks, D; Karnachuk, OV; Parnachev, VP; Holden, W; Frengstad, B (2002). Groundwater contamination from rural pit latrines: examples from Siberia and Kosova. $\quad J . \quad$ Chartered Inst. Water Environ. Manage. 16(2):147152.

Benjamin, SN; James, HE (2014). Sachet Water Quality in Obuasi, Ashanti Region, Ghana. Journal of Biology, Agriculture and Healthcare ISSN 2224-3208 (Paper) ISSN 2225- 093X

(Online) 4(5): 2014

Blackburn, BG; Craun, GF; Yoder, JS; Hill, V; Calderon, RL; Chen, N; Lee, SH; Levy, DA; Beach, MJ (2004). Surveillance for waterbornedisease outbreaks associated with drinking water-United States, 2001-2002. MMWR Surveillance Summary 53(8): 23-45.

Brinkhoff, T (2010). City Population. http://www.citypopulation.de [Accessed 12 June 2015]

Cairncross, S (2004). The Case for Marketing Sanitation. WSP Field Notes. World and Sanitation Program, Africa, Nairobi.

Dzwairo, B; Hoko, Z; Love, D; Guzha, E (2006). Assessment of the impacts of pit latrines on groundwater quality in rural areas: a case study from Marondera district, Zimbabwe. Phys Chem. Earth. 31(15-16):779-788.

EPA (2009). Analytical Methods Approved for Drinking Water Compliance Monitoring under the Total Coliform Rule. Available at: http://www.standardmethods.org/ [Accessed 24 April 2016].
Fewtrell, L (2004). Drinking-water nitrate, methemoglobinemia, and global burden of disease: a discussion. Environ Health Perspect. 112:1371-1374.

Harilal, CC; Hashim, A; Arun, PR; Baji, S (2004). Journal of Ecology, Environment and Conservation. 10(2): 187-192.

Hendriksen, A; Tukahirwa, J; Oosterveer, PJM; Mol, APJ (2012). Participatory Decision Making for Sanitation Improvements in Unplanned Urban Settlements in East Africa. Journal of Environment \& Development. 21(1): 98-119

Hutton, G; Haller, L (2004). Evaluation of the Costs and Benefits of Water and Sanitation Improvements at the Global Level, Water, Sanitation and Health Protection of the Human Environment World Health Organization Geneva 2004.

Hutton, G; Haller, L; Bartram, J (2007). Economic and health effects of increasing coverage of low cost household drinking-water supply and sanitation interventions to countries offtrack to meet MDG target 10. Geneva, Switzerland, World Health Organization; http://www.irc.nl/page/38443 [Accessed on 22 April 2014]

IARC (2005). IARC Monographs on the Evaluation of Carcinogenic Risks to Humans. Ingested Nitrates and Nitrites. Vol 94. Available at:

http://monographs.iarc.fr/ENG/Meetings/index1.php [Accessed 12 June 2015].

John, G.L (2009). Water and Sanitation Summary Sheet from Water and Sanitation

Krometis, LH; Characklis, GW; Drummey, PN; Sobsey, MD (2010) Comparison of the presence and partitioning behaviour of indicator organisms and Salmonella spp. in an urban watershed. Journal of Water and Health. 8(1): 44-59

Ministry of Local Government and Rural Development (MLGRD) and Local Government Service (LGS) (2010). Guidelines for the Provision, Operation, Maintenance and Management of Public Toilets in Ghana (Revised August 2010). Accra: MLGRD.

Mor, S; Ravindra, K; Dahiya, RP; Chandra, A (2006). Leachate Characterization and assessment of groundwater pollution near 
municipal solid waste landfill site. Environ. Monit. $\quad$ Assess., 4: 325-334.

Nigerian Industrial Standard, (2007). Nigerian Standard for Drinking Water Quality. NIS 555:2007. Standards Organization of Nigeria.

Nigerian Red Cross Society (2011). International Federation's Disaster Relief Emergency Fund (DREF). Nigeria; Cholera Outbreak

Oke, MO; Atinsola, MA; Aina, M (2013). Evaluation of Sanitation Practices in Ibadan South East LGAs of Oyo State, Nigeria. Academic Journal of Interdisciplinary Studies Published by MCSER-CEMAS-Sapienza, University of Rome.

Olowe, OA; Ojurongbe, O; Opaleye, OO; Adedosu, OT; Olowe, RA; Eniola, KIT (2005). Bacteriological quality of water samples in Osogbo metropolis. African Journal of Clinical and Experimental Microbiology 6(3):23-26

Osumanu, IK; Kosoe, EA (2013). Where do I answernature's call? An assessment of accessibility and utilisation of toilet facilities in Wa, Ghana. Ghana Journal of Geography 5:17 $-31$

Osumanu, IK (2007). Household environmental and behavioural determinants of childhood diarrhoea morbidity in the Tamale Metropolitan Area (TMA), Ghana. Danish Journal of Geography 107(1): 59-68.

Songsore, J; McGranahan, G (1998). The Political economy of household environmental management: gender, environment and epidemiology in the Greater Accra Metropolitan Area. World Development 26(3): 395-412.

Verhille, S (2013). Understanding microbial indicators for drinking water assessment: interpretation of test

results and public health significance. National Collaborating Centre for Environmental Health.

Wade TJ; Pai, N; Eisenberg, JN; Colford, JM. Jr. (2003). Do U.S. Environmental Protection Agency water quality guidelines for recreational waters prevent gastrointestinal illness? A systematic review and metaanalysis. Environ Health Perspect. 111:11021109.
Washington State Department of Health. 2012. Coliform bacteria in drinking water - Total coliform, faecal coliform and E. coli (figure). Available at:

http://www.doh.wa.gov/CommunityandEnviron ment/DrinkingWater/Contaminants/Coliform.asp x. [Accessed 12 June 2015].

WHO (2011a). Guidelines for Drinking-water Quality 2011 (4th Ed.). Geneva: World Health Organization. Available at:

http://www.who.int/water_sanitation_health/publ ications/2011/dwq_guidelines/en/index. html [Accessed 12 June 2015].

WHO (2011b). Nitrate and nitrite in drinking water. Background document for preparation of WHO Guidelines for Drinking-water Quality. Geneva, World Health Organization

(WHO/SDE/WSH/07.01/16Rev/1). Available at:http://www.who.int/water_sanitation_health/d wq/chemicals/nitratenitrite2ndadd.pdf

[Accessed 12 June 2015]

WHO (2012). Prevention and control of cholera outbreaks: WHO policy and recommendations Available at: http://www.who.int/cholera/technical/prevention/ control/en/index.html. [Accessed 28 April 2016]

WHO/UNICEF Joint Monitoring Programme (JMP) for Water Supply and Sanitation (2012). Progress on Sanitation and Drinking-Water, 2012 Update.United Nations Children's Fund and World Health Organization, New York and Geneva, 2012, p. 15.

World Health Organization (WHO) (2002). The World Health Report 2002, Reducing Risks, Promoting Health Life.

World Health Organization. (2009). Global Health Risks: Mortality and Burden of Disease attributable to selected major risks. Geneva

World Health Organization. (2010). Cholera. Fact sheet no. 107. Geneva: World Health Organization; [Available from:

http://www.who.int/mediacentre/factsheets/fs107/en/i ndex.html [Accessed 28 April 2016] 